\title{
STRABISMUS AS A POSSIBLE SIGN OF SUBCLINICAL MUSCULAR DYSTROPHY PREDISPOSING TO RHABDOMYOLYSIS AND MYOGLOBINURIA: A STUDY OF AN AFFECTED FAMILY
}

\author{
K.B. LEWANDOWSKI
}

\begin{abstract}
Administration of succinylcholine to normal individuals results in alterations in muscle membrane integrity expressed as a slight increase in the concentrations of creatine phosphokinase (CK) in serum and appearance of small amounts of myoglobin in the urine, but without clinical symptoms. Subjects with strabismus due to congenital muscular dystrophy may develop more significant rhabdomyolysis expressed as muscle stiffness and weakness, massive myoglobinuria, marked elevation of senum CK and other enzymes, metabolic acidosis, tachycardia and moderate elevation of body temperature. In some cases grave malignant hyperthermia with significant hypoxia, metabolic acidosis, tachycardia and marked abnormalities in serum electrolyte concentrations may cause irreversible damage to the central nervous system and other vital organs and death.

A case of difficult anaesthesia for a six year old boy belonging to family affected with muscular dystrophy is presented. More attention must be given to preoperative examination (anamnesis, serum enzymes) of ophthalmological patients and more careful monitoring during anaesthesia and in the early postoperative period must be instituted to prevent and treat complications induced by succinylcholine and volatile anaesthetic agents.
\end{abstract}

KEY WORDS: COMPLICATIONS, muscular dystrophy, strabismus, thabdomyolysis, myoglobinuria, malignant hyperthermia.

A PREVIOUSLY HEALTHY six year old boy was presented for correction of divergent strabismus of the right eye. The child had been anaesthetized uneventfully six months earlier for the same operation on his left eye. He had no allergies and was considered a minor anaesthetic risk (group 1). On the morning of the operation his blood pressure, pulse, body temperature, haemoglobin and blood leucocytes were normal. Forty-five minutes before anaesthesia, the patient received meperidine $17.5 \mathrm{mg}$ and atropine $0.25 \mathrm{mg}$ intramuscularly (weight $17.5 \mathrm{~kg}$ ). The patient arrived in the operating room well sedated and cooperative. Ten minutes before the start of the anaesthetic methohexitone $120 \mathrm{mg}$ was given by rectum. Anaesthesia was started by a junior member of staff with nitrous oxide and oxygen, four litres per minute of each, and halothane $0.5-2.0$ per cent given by mask from a Jackson-Rees system. After the patient had reached the surgical level of anaesthesia, succinylcholine chloride $25 \mathrm{mg}$ was injected intravenously. The muscle fasciculation was unusually strong and tracheal intubation could not be

K.B. Lewandowski, M.D., Central Hospital of St. Michel, P1 8750101 Mikkeli 10, Finland.

Can. Anaesth. Soc. J., vol. 29, no. 4, July 1982 done because of the stiffness of the jaw. Repeated doses of succinylcholine $10 \mathrm{mg}$ and thiopentone $30 \mathrm{mg}$ were given to achieve better relaxaon. The intubation was accomplished with difficulty, the jaw remaining stiff. After intubation the heart rate rose from 140 to 170 beats per minute. The monitor showed sinus tachycardia. Anaesthesia was continued with 3 litres/min nitrous oxide, 3 litres/min oxygen and halothane 1.5 per cent. There was no cyanosis. Meperidine $10 \mathrm{mg}$ was given intravenously for analgesia. Ventilation had to be assisted for 10 minutes The operation started 15 minutes later and lasted for 25 minutes. During the first 30 minutes of anaesthesia the blood pressure remained stable (105-110 $\mathrm{mmHg}$ ) but ventricular and supraventricular extrasystoles were seen on the monitor and tachycardia up to 180 beats per minute was observed. The surgeon was informed of the difficulties and asked to finish the operation as quickly as possible. The halothane concentration was diminished to one per cent because the blood pressure fell to $85 \mathrm{mmHg}$. The respiratory frequency was 38 breaths per minute and there was no cyanosis. The patient's body temperature was not measured during the anaesthetic. Forty-five minutes after the start of anaesthesia the trachea 
TABLE I

Results of Clinical Laboratory Tests

\begin{tabular}{|c|c|c|c|c|c|}
\hline \multirow{2}{*}{$\begin{array}{c}\text { Serum normal } \\
\text { value }\end{array}$} & \multirow{2}{*}{$\begin{array}{l}\text { Day of } \\
\text { operation }\end{array}$} & \multicolumn{4}{|c|}{ After Operation } \\
\hline & & lst day & 2nd day & 3rd day & 4th day \\
\hline CK 0-160 u/litre & 6900 & 10100 & 4300 & 1300 & 994 \\
\hline Aldolase $0-3.1 \mathrm{u} /$ litre & 4.5 & 6.5 & 10.8 & & \\
\hline LD 0-500 w/litre & 650 & 1100 & & & \\
\hline $\mathrm{pH}$ & $7.29 \quad 7.42$ & normal & & & \\
\hline $\mathrm{PCO}_{2}(\mathrm{kPa})$ & $5.2 \quad 4.3$ & normal & & & \\
\hline BE (mmol/litre) & $-7.2-2.8$ & normal & & & \\
\hline $\mathrm{PO}_{2}(\mathrm{kPa})$ & 22.313 .8 & & & & \\
\hline \multirow{2}{*}{$\begin{array}{l}\text { serum creatinine } \\
\text { micromol/litre }\end{array}$} & & & & & \\
\hline & 108 & 44 & & & \\
\hline \multicolumn{6}{|l|}{ Urine } \\
\hline occult blood & $++t$ & $+t+$ & - & - & - \\
\hline myoglobin & + & + & - & - & - \\
\hline ketones & ++ & - & - & - & - \\
\hline glucose & + & - & - & - & - \\
\hline
\end{tabular}

was extubated and the patient was transferred to the recovery room where he received six litres/ min oxygen by a mask and five per cent glucose intravenously. The blood pressure was stable, the respiratory frequency fell to 28 breaths per minute and cyanosis was absent. One hour later, when the child could not be wakened, the senior anaesthetist was consulted. Sinus tachycardia of $140 / \mathrm{min}$, stiffness of the extended limbs and unusually warm skin aroused the suspicion of malignant hyperpyrexia and/or rhabdomyolysis. The rectal temperature was $37.8^{\circ} \mathrm{C}$ and from this point on measurements were made at frequent intervals. Astrup analysis was $\left[\mathrm{H}^{+}\right]$a 51.29 $\mathrm{nmol} / 1$ (pH 7.29) $\left(\mathrm{PcO}_{2} 5.2 \mathrm{kPa}, \mathrm{BE}-7.2 \mathrm{mmol} / \mathrm{l}\right.$ and capillary $\mathrm{PO}_{2} 22.3 \mathrm{kPa}$. Fifty $\mathrm{ml}$ of $7.5 \mathrm{per}$ cent solution of sodium bicarbonate given slowly intravenously corrected the metabolic acidosis. Surface cooling was started with electric fans and ice bags applied to the axillas, groin and chest. Laboratory examination showed elevation of serum CK, aldolase and LD (Table I). Serum potassium and sodium were normal. Gradually the patient's body temperature, pulse and respiratory rate fell to normal and he regained consciousness, though he was very tired and not willing to speak or to sit. The tendon reflexes were absent. The rate of infusion of intravenous fluids was increased to achieve diuresis, but without effect. Six hours after anaesthesia the patient voided spontaneously only $50 \mathrm{ml}$ of urine, which showed a positive test for occult blood but no red cells on microscopic examination. A test for urine ketones was strongly positive, while urine sugar was slightly positive and blood glucose was normal. The urine specimen was sent for myoglobin determination. Electrophoretic examination of the urine showed large amounts of myoglobin. (The result arrived some days later.)

Furosemide $5 \mathrm{mg}$ was given intravenously, resulting in a marked improvement in diuresis and $a$ fall in the serum creatinine level from $108 \mathrm{mmol} / 1$ on the evening of the operation to $44 \mathrm{mmol} / \mathrm{l}$ the next morning. During the first 24 hours the patient received $1900 \mathrm{ml}$ of intravenous fluids and voided more than $1180 \mathrm{ml}$ of urine. A clinical neurological examination the next day showed no physical abnormalities except for the muscle weakness and inability to walk. The muscle weakness lasted two days. Thoracic $x$-ray and electrocardiogram were normal. An electromyogram taken later was also normal.

The clinical condition of the patient gradually improved and on the fifth postoperative day he was discharged fit and well. However, his serum CK remained elevated at $994 \mathrm{u} /$ litre and his MM fraction was also increased to 0.98 .

The patient had been anaesthetized six months earlier with nitrous oxide, oxygen and enflurane. Succinylcholine, methohexitone and thiopentone were also used. The course of the anaesthetic was normal except for tachycardia up to 138 beats per minute. The body temperature was not measured.

The patient's parents and other relatives were informed of the nature of the event and were studied to establish whether they were prone to MH and/or myoglobinuria. They were subjected 
to careful clinical examination, and a chest $x$-ray and electrocardiogram were taken. The resting levels of serum CK, aldolase and LD were determined.

\section{Results Of The Study Of Close Relatives}

The patient's brother had never been anaesthetized. The patient's mother and father had been anaesthetized uneventfully. The records of anaesthesia were not available.

The relatives did not have any subjective symptoms of muscle disease. The only abnormality detectable on clinical examination was strabismus in the original patient and exophory and anaphory in his ten year old brother. The 12 year old brother had scoliosis of the thoracic spine that was only detectable radiologically. The resting levels of serum lactic dehydrogenase were $560 \mathrm{w} /$ litre and $510 \mathrm{u} /$ litre (normal $0-500 \mathrm{u} /$ litre) in the patient and his 10 year old brother, respectively. Serum CK was normal in all subjects.

\section{Detailed Neurological Examination of Distant Relatives}

The father's cousin was free from muscle disease. However, he had retired because of heart insufficiency due to cardiomyopathy of unknown origin. The thoracic $x$-ray showed scoliosis of the thoracic spine. His 15 year old son was suffering from well advanced Duchenne dystrophy and was confined to a wheelchair. He had been anaesthetized once with halothane without complication, for muscle biopsy. His 27 year old son had no history or symptoms of muscle disease.

\section{Discussion}

Myoglobinura is a chemical finding which denotes previous muscle damage but is not a nosologic entity in itself. The factors which may cause the phenomenon of myoglobinuria are congenital errors in metabolism (McArdle's disease due to absent muscle phosphorylase), muscle trauma (crush injury), and poisoning of the metabolic system (alcohol or bariturate intoxication). ${ }^{1}$ Myoglobinuria may occur after general anaesthesia, but only rarely. Succinylcholine, especially during halothane anaesthesia, causes elevation of the serum enzymes normally found in large amounts in muscles. Previous studies have shown that administration of succinylcholine to normal individuals results in some alterations in muscle membrane integ- rity expressed as an increase in the levels of serum enzymes such as creatine phosphokinase (CK). ${ }^{2}$ Halothane not only potentiates the effect of succinylcholine but also produces the same changes when administered alone, ${ }^{3}$ though to a lesser extent.

In 1966 it was observed that administration of succinylcholine to a number of children did not produce relaxation, but caused paradoxical muscle spasm and rigidity of striated muscles and made traceal intubation difficult. This was followed by elevation of the body temperature to $41^{\circ} \mathrm{C}$, myoglobinuria on the first day of anaesthesia, and muscle weakness and hyperaesthesia for several days. Elevation of creatine phosphokinase, aldolase, lactic dehyrogenase and other enzymes in the serum was also observed.' Succinylcholine caused a type of muscle destruction known as rhabdomyolysis. ${ }^{4}$

Furthermore, it was observed that succinylcholine may cause an even more serious adverse reaction, which is associated with severe elevation of body temperature and known as malignant hyperpyrexia.

The untoward reaction to succinylcholine is probably due to a genetic alteration of the receptor protein, resulting in changes ranging from muscle rigidity with minimal rhabdomyolysis and slight elevation of body temperature to massive myolysis, myoglobinaemia, myoglobinuria, malignant hyperpyrexia, cyanosis, metabolic acidosis and possibly death. ${ }^{1,5,6}$

In the present case rhabdomyolysis and myoglobinura were suspected as a result of monitoring the clinical course of the early postanaesthetic period (still unconscious one hour after anaesthesia, stiffness of muscles, and moderate elevation of body temperature). The diagnosis was confirmed by the elevated level of senum enzymes and metabolic acidosis. The patient voided a small amount of urine as late as five hours after anaesthesia. The urine showed a positive reaction to blood, though without the presence of red cells on microscopic examination. The urine was sent for electrophoretic examination but the result for myglobin (strongly positive) did not arrive until some days later.

The body temperature was lowered using surface cooling with ice bags and electric fans, so intragastric or rectal cooling was not necessary. Myoglobinuria and oliguria were treated with vigorous intravenous fluid administration and furosemide. Metabolic acidosis was corrected by a single infusion of 7.5 per cent sodium bicarbonate. It must be stressed that succinyl- 
choline induced rhabdomyolysis and myoglobinuria may cause more significant acute renal failure $^{7}$ and more drastic therapy may be necessary, including larger doses of diuretic and mannitol. Serum creatinine and potassium must be measured and corrected.

The serum CK rise was very significant in this case and there were serious disturbances in heart rhythm (tachycardia and extrasystoles), which agrees with the report by Schaer, et al. ${ }^{8}$ who reported that rhabdomyolysis twice caused cardiac arrest during anaesthesia because of rapid serum electrolyte changes (hypocalcaemia).

Rhabdomyolysis and pyrexia may have occurred because, instead of causing the usual transistory muscle fasciculation followed by relaxation, succinylcholine produced fasciculations followed by massive and sustained muscle contraction.

Previous studies 9 have shown that myoglobinuria occurs after four intermittent doses of succinylcholine given during halothane anaesthesia and that precurarisation protects the patient from an increase in serum creatine phosphokinase and prevents myoglobinuria. ${ }^{10}$

The present study agrees with previous reports that even two doses of succinylcholine may be sufficient to cause myoglobinuria. " Rhabdomyolysis and myoglobinura may occur after single doses of succinylcholine. ${ }^{12}$

The important finding in this study is that the patient's ten year old brother was also affected by strabismus and also had a slightly elevated serum lactic dehydrogenase level. ${ }^{13}$ His 12 year old brother had scoliosis of the thoracic spine. Strabismus, scoliosis, elevated serum LD, abnormal response to succinylcholine, considerably increased MM fraction of serum CK of the patient on the fifth postoperative day and muscle dystrophy in the father's cousin's son shows, with high probability, that the family is affected by subclinical dystrophy. The family is possibly prone to $\mathrm{MH}$ and/or rhabdomyolysis. ${ }^{14}$

The study shows that looking only for elevated serum CK may cause subjects with elevated serum lactic dehydrogenase, scoliosis (sign of weakness of paravertebral muscles) or strabismus due to subclinical dystrophy to be missed. The present study confirms the theory that relatives (even distant ones) of patients affected with muscular dystrophy may be prone to $\mathrm{MH}$ and/or rhabdomyolysis.

Contrary to the previous report ${ }^{12}$ the thabdomyolysis occurred in a subject with a normal resting level of serum CK. The possibility of
McArdle's disease was eliminated by an ischaemic forearm test and dystrophia myotonica in the patient and his relatives was excluded by clinical examination. It is interesting to note that LD was the only enzyme elevated in the serum of the patient and his brother.

The patient had previously been anaesthetized for strabismus. Although enflurane and succinylcholine had been used, the course of anaesthesia was normal. However, a normal previous anaesthetic does not exclude the possibility of rhabdomyolysis and myoglobinuria ${ }^{11}$ or malignant hyperpyrexia. The child's father had been anaesthetized uneventfully for an operation for varicose veins. Incomplete relaxation, rigidity or stiffness of striated muscles, or unexplained tachycardia during anaesthesia must be considered a warning sign of myoglobinuria or malignant hyperpyrexia (MH). The body temperature must be measured, blood gas analysis carried out and, in the event of $\mathrm{MH}$, halothane or other volatile anaesthetics must be stopped and anaesthesia continued with pure oxygen and analgesics. Active surface cooling must be started using ice bags; intragastric and rectal cooling can also be used. Abnormalities in serum electrolytes such as hyperkalaemia or hypokalaemia and metabolic acidosis must be corrected. ${ }^{6,15}$

Anaesthetists must be more alert to the possibility of $\mathrm{MH}$ and/or rhabdomyolysis and myoglobinuria during anaesthesia and in the early postoperative period. Stiffness of the jaw during intubation and unexplained tachycardia should arouse suspicion. An elevated body temperature, metabolic acidosis and a significant rise in serum CK confirm the diagnosis. Vigorous treatment must be instigated. It is important to remember that about 30 per cent of $\mathrm{MH}$ is in the flaccid form, in which there is no muscle rigidity.

The author has seen and participated in the treatment of three patients in which succinylcholine had an adverse effect on striated muscles. In each case suspicion was aroused well after anaesthesia, although signs of $\mathrm{MH}$ in the first case and rhabdomyolysis in the second and third cases clearly occurred during anaesthesia. The first patient, a 36 year old woman, died for unknown reasons during anaesthesia in 1966. Careful examination of the blood relatives of the patient six years later showed that they were suffering from muscular dystrophy and had elevated serum CK, aldolase and LD. These findings, together with the unusually strong fasciculations, stiffness of the jaw, tachycardia, 
cyanosis and use of a hot absorber during anaesthesia, lead to the diagnosis of $\mathrm{MH}^{6}{ }^{6}$

The second patient, a four year old boy, was anaesthetized in 1973. Rhabdomyolysis and myoglobinuria were diagnosed five hours after anaesthesia, when the patient voided dark brown urine and showed muscle weakness. ${ }^{12}$

The third patient (the present case) had still not regained consciousness one hour after anaesthesia, his limbs were extended, he showed tachycardia and was unusually warm.

More effort must be made to prevent $\mathrm{MH}$ and myoglobinuria through preoperative screening of serum CK, aldolase and LD whenever possible, and through screening of families affected with muscular dystrophy, dystrophia myotonica and myopathy, for humanitarian, medical and legal reasons. Preoperative screening for these three enzymes could possibly have prevented death in the first case and the rhabdomyolysis and myoglobinuria in the second and third.

Elevated serum enzymes and strabismus or scoliosis of the thoracic spine may be useful signs for prediction of susceptibility to the potentially lethal complication of general and local anaesthesia. It must be remembered that serum CK may also be elevated for reasons other than myopathy. Pregnancy, trauma, myocardial infarction and alcoholism are other conditions which need to be remembered. ${ }^{13}$

An association has been reported between MH, squint and ptosis. ${ }^{16,17}$ The present sudy shows that strabismus patients may be prone to rhabdomyolysis and myoglobinuria.

\section{REFERENCES}

1. Auerbach, V.H., Digeorge, A.M., Mayer, B.W., Hayden, M., CarPenter, G.G., KrumPERMAN, L. \& TRUTER, T.R. Rhabdomyolysis and Hyderpyrexia in Children after Administration of Succinylcholine. Int. Symp. on malig. hyperther. Charles C. Thomas, 30-51 (1973).

2. TAMmisto, T. \& AiraKsinen, M. Increase of Cratine Kinase Activity in Serum as a Sign of Muscular Injury Caused by Intermittently Administered Suxamethonium during Halothane Anaesthesia. Brit. Jour. Anaesth. 38: 510 (1966).

3. Pearson, C.M., Beck, W.S. \& Bladh, W.H Idiopathic Paroxysmal Myoglobinuria. AMA Arch. Inter Med. 99: 376 (1957).
4. MacLaren, C.A.B. Myoglobinura Following the Use of Suxamethonium Chloride. Brit. Jour. Anaesth. 40: 901-902 (1968).

5. Aldrete, J.A., Padfield, A., Solomon, C.C. \& Rubright, M.W. Possible Predictive Test for Malignant Hyperthermia During Anaesthesia. JAMA 215: 1465 (1971).

6. Lewandowski, K.B., Hollmén, A. \& ReunANEN, M. Malignant Hyperpyrexia. A Study of an Affected Family. Ann. Chir. et Gynn Fenniae 64: 112 (1975).

7. BenLike, K.A. \& JARnum, S. Myoglobinura with Acute Renal Failure Possibly Induced by Suxamethonium. A Case Report. Brit. Jour. Anaesth. 36: 730-736 (1964).

8. Schaer, H., Steinmann, B., Jerusalem, S. \& MAIER, C. Rhabdomyolysis Induced by Anaesthesia with Intraoperative Cardiac Arrest. Brit. Jour. Anaesth. 49: 495 (1977).

9. AIRAKSINEN, M. \& TAMMISTO, T. Myoglobinura after Intermittent Administration of Succinylocholine During Halothane Anaesthesia. Clin. Pharmacol. Ther. 7: 583-587 (1966).

10. Tammisto, T., Leikkonen, P. \& Airaksinen, $M$. The Inhibitory Effect of d-Tubocurarine on the Increase of Serum Creatine Activity Produced by Intermittent Suxamethonium Administration During Halothane Anaesthesia. Acta Anaest. Scand. 11: 333-340 (1967).

11. MOORE, W.E., WatSON, R.L. \& SUmmary, J.J. Massive Myoglobinura Precipitated by Halothane and Succinylocholine in a Member of a Family with Elevation of Serum Creatine Phosphokinase. Anesth. Analg. Current Researches. 55: 680-682 (1976)

12. Lewandowskı, K.B. Rhabdomyolysis Myoglobinuria and Hyperpyrexia Caused by Suxamethonium in a child with Increased Serum CK Concentration. Brit. Jour. Anaesth. 52: 981-984 (1981).

13. Tammisto, T., Brander, P., Airaksinen, M., TOMmILA, V. \& Lintola, J. Strabisumus as a Possible Sign of Latent Muscular Disease Predisposing to Suxamethonium-Induced Muscular Injury. Ann. Clin. Res. 2: 126-130 (1970).

14. KING, J.O., DENBOROUGH, M.A. \& ZAPF, P.W. Inheritance of Malignant Hyperpyrexia, Lancet 1: 365 (1972).

15. Relton, J.E.S., Britt, B.A. \& Steward, D.J. Malignant Hyperpyrexia. Brit. Jour. Anaesth. 45: 272 (1973).

16. KING, J.O. \& Denborough, M.A. AnaestheticInduced Malignant Hyperthermia in Children. J. Pediatr. 81: 37-40 (1973)

17. BRITt, B.A., KWONG, F.H.-F. \& ENDERNYI, L. The Clinical and Laboratory Features of Malignant Hyperthermia. A Review, in Henschel, E.O., Malignant Hyperthermia, current concepts, New York, Appleton Century Crofts, 9-45 (1977) 